Volume 10 Nomor 1, November 2018, p.096-100

Faculty of Law, Universitas Kristen Maranatha

ISSN: 2085-9945 I e-ISSN: 2579-3520

Nationally Accredited Journal by SINTA

\title{
Tinjauan Hukum Perbedaan Pengalihan Hak Paten dengan Perjanjian Lisensi pada Hukum Perdata
}

\author{
1. Tasya Safiranita Ramli
}

\author{
2. Sherly Ayuna Putri \\ Faculty of Law, Universitas Padjadjaran \\ tasya_safiranita@yahoo.com
}

Submitted: 2018-08-20; Reviewed: 2018-09-05; Accepted: 2018-11-26

\begin{abstract}
Patent is a part of intellectual property. The object of patent shall be an exclusive right granted by the state to the inventor of his invention in the field of technology for a certain period of time carrying on the invention himself or giving approval to another party to exercise it. In this case the patent is very encouraging for patents to be transferred or either because of inheritance, grant, will, written agreement, or other reasons under the applicable laws and regulations. Licenses are granted by the Patent Holder, either exclusively or non-exclusively, to a licensee under a written agreement to use a Patent that is still protected within a certain time period and conditions. The transfer of a Patent whose ownership of the rights also switched, the License through an agreement is essentially a grant of the right to enjoy the economic benefits of a Patent within a certain time and condition.

The License Agreement may include all or part of the action. The Patent Holder in this case shall still be entitled to exercise on own Patent, unless otherwise agreed. The license constitutes a contractual agreement of two business entities granted to a person who holds a license for patents, marks and other property rights in an exchange of fees or royalties. According to them licenses can also allow for skills, profits, capital, or other capacity. Licensing is usually used by manufacturers to enter in other domestic markets where they have no expertise.

License is an agreement to grant property or privilege to do production and use something. In this case it is not included with the right of direct selling. In addition, there is still a meaning of the word license which says that a license is a permit granted by a competent authority, in which an unauthorized act would be considered an offense. This creates the license as a given authority in the form of the right to do something.
\end{abstract}

Keywords: Agreement, Invention, License, Patent, and Profits. 


\section{PENDAHULUAN}

Dalam hal ini Paten merupakan suatu hak khusus berdasarkan Undang-Undang yang diberikan kepada inventor atau menurut hukum pihak yang berhak memperolehnya, (UU Paten Indonesia menyebutnya dengan istilah Inventor dan istilah temuan disebut sebagai Invensi) atas permintaannya yang diajukannya kepada pihak penguasa, bagi temuan baru di bidang teknologi, perbaikan atas temuan yang sudah ada, cara kerja baru, atau menemukan suatu perbaikan baru dalam cara kerja, untuk selama jangka waktu tertentu yang dapat diterapkan dalam bidang industri.

Dapat disimpulkan bahwa paten diberikan bagi ide dalam bidang teknologi dan teknologi pada dasarnya adalah berupa ide (immateril) yang dapat diterapkan dalam proses industri. Teknologi pada dasarnya lahir dari karsa intelektual, sebagai karya intelektual manusia. Karena kelahirannya telah melibatkan tenaga, waktu, dan biaya (berapapun besarnya misalnya dalam kegiatan penelitian), maka teknologi memiliki nilai atau sesuatu yang bernilai ekonomi, yang dapat menjadi objek harta kekayaan (property). Dalam ilmu hukum, yang secara luas dianut oleh bangsa-bangsa lain, hak atas daya pikir intelektual dalam bidang teknologi tersebut diakui sebagai hak kekayaan yang sifatnya tidak berwujud. Hak seperti inilah yang dikenal sebagai "Paten".

Menurut Undang-Undang Nomor 13 tahun 2016, terdapat 2 jenis paten yaitu paten biasa dan paten sederhana. Paten biasa adalah paten yang melalui penelitian atau pengembangan yang mendalam dengan lebih dari satu klaim. Paten sederhana adalah paten yang tidak membutuhkan penelitian atau pengembangan yang mendalam dan hanya memuat satu klaim. Pada awalnya, timbulnya paten terjadi pada saat sepuluh negara-negara peserta asli (original members) dan tujuh negara (Denmark, Japan, Luxemburg, Monaco, Montenegro, Norwegia, dan Sweden) yang menjadi peserta dengan cara menandatangani naskah asli Konvensi Bern. Latar belakang diadakannya Konvensi seperti tercantum dalam Mukadimah naskah asli Konvevsi Bern adalah: "...being equally animated by the desire to protect, in as effective and uniform a manner as possible, the right of authors in their literary and artistic works".

Berdasarkan naskah tersebut, dapat diartikan sebagai suatu badan yang memiliki kesamaan hidup berdasarkan keinginan untuk melindungi, serta keberhasilan dan keseragaman dengan sikap atau cara yang mendukung oleh penulis kesusastraan dan artistik. Setelah berlakunya Konvensi Bern yang tergolong sebagai Law Making Treaty, terbuka bagi semua negara yang belum menjadi anggota, keikutsertaan sebagai negara anggota baru harus dilakukan dengan cara meratifikasinya dan menyerahkan naskah ratifikasi kepada Direktur Jenderal WIPO. Dalam hal ini, Penelitian ini ditujukan untuk mengetahui batasan invensi yang dapat di daftarkan di Indonesia dan untuk mengetahui keterkaitan antar inventor dalam suatu temuan. 


\section{PEMBAHASAN}

\section{Tinjauan Umum dan Permasalahan Teknologi dengan paten.}

Sejalan dengan perkembangan manusia yang dinamis, hukum semestinya harus dapat mencakup perkembangan manusia di dalam segala aspek termasuk perkembangan di dalam aspek teknologi. Hadirnya media sebagai bentuk perkembangan teknologi manusia di bidang teknologi informatika membawa dampak-dampak yang beragam bagi para pihak yang terkait.

Memasuki abad 21, teknologi komunikasi memegang peranan penting dalam berbagai sektor masyarakat seluruh dunia. Semakin berkembang dan semakin kompleksnya aktivitas masyarakat dunia, maka menjadi pendorong bagi perkembangan teknologi di bidang komunikasi. ${ }^{1}$ Berdasarkan hal tersebut, teknologi komunikasi dituntut dan mengarah kepada efisiensi dan dapat menembus batasan wilayah yang tanpa dihalangi oleh batas negara, tanpa dibatasi waktu. Salah satu teknologi yang berhasil menjawab kebutuhan tersebut adalah internet. ${ }^{2}$

Internet dapat diartikan sebagai jaringan komputer luas dan besar yang mendunia, yaitu menghubungkan pemakai komputer dari suatu negara ke negara lain di seluruh dunia, dimana di dalamnya terdapat berbagai sumber daya informasi dari mulai yang statis hingga yang dinamis dan interaktif. ${ }^{3}$

\section{Perbedaan Pengalihan Paten dan Lisensi Paten}

Hak paten sebagaimana diatur dalam Pasal 74 ayat 1 Undang - undang Nomor 13 Tahun 2016 Tentang Paten dapat beralih atau dialihkan baik seluruhnya maupun sebagian karena:
a. pewarisan;
b. hibah;
c. wasiat;
d. wakaf;
e. perjanjian tertulis; atau
f. sebab lain yang dibenarkan berdasarkan ketentuan peraturan perundang- undangan.

Pengalihan hak atas Paten harus disertai dokumen asli Paten berikut hak lain yang berkaitan dengan Paten. Segala bentuk pengalihan hak atas Paten harus dicatat dan diumumkan dengan dikenai biaya. Lisensi adalah izin yang diberikan oleh Pemegang

\footnotetext{
${ }^{1}$ Tymutz. 2009. Teknologi Informasi Untuk Keunggulan Kompetitif Dalam Operasional Perusahaan.

2 Tim Lindsey, Hak Kekayaan Intelektual Suatu Pengantar, Bandung: Alumni, 2006, hlm. 161.

3 Dewi Astutty Mochtar, Perjanjian Lisensi Alih Teknologi Dalam Pengembangan Teknologi Indonesia, Bandung: Alumni, Bandung, 2001.
} 
Paten, baik yang bersifat eksklusif maupun non-eksklusif, kepada penerima lisensi berdasarkan perjanjian tertulis untuk menggunakan Paten yang masih dilindungi dalam jangka waktu dan syarat tertentu-dalam hal lain yang dimaksud dengan perjanjian Lisensi eksklusif merupakan perjanjian yang hanya diberikan kepada satu penerima Lisensi, dan/atau dalam wilayah tertentu. Sementara, yang dimaksud dengan perjanjian Lisensi non-eksklusif merupakan perjanjian yang dapat diberikan kepada beberapa penerima Lisensi dan/atau dalam beberapa wilayah.

Pemegang Paten berhak memberikan Lisensi kepada pihak lain berdasarkan perjanjian Lisensi baik eksklusif maupun non-eksklusif untuk melaksanakan:

1. dalam hal Paten-produk: membuat, menggunakan, menjual, mengimpor, menyewakan, menyerahkan, atau menyediakan untuk dijual atau disewakan atau diserahkan produk yang diberi Paten;

2. dalam hal Paten-proses: menggunakan proses produksi yang diberi Paten untuk membuat barang atau tindakan lainnya sebagaimana dimaksud dalam huruf a.

\section{Hubungan Paten dan Hukum Perdata}

Selain itu ada aturan lain, bahwa pemegang paten dapat memberi lisensi atas perijinan kepada orang lain untuk memakai buah pikiran yang tertuang ke dalam paten itu, seluruhnya atau sebagian. Dengan adanya pengalihan atau penyerahan paten kepada orang lain, beralih atau diserahkan pula kekuasaan atas paten tersebut. Disini yang beralih atau diserahkan hanyalah hak ekonomisnya saja, sedangkan hak moralnya tidak ikut serta beralih atau diserahkan, karena tetap melekat pada diri Inventornya.

Paten sebagai suatu hak yang diberikan kepada seseorang atas suatu penemuan yang megandung langkah inveritif (keharusan) dapat dialihkan kepada orang lain. Pengertian pengalihan hak adalah penyerahan kekuatan/kekuasaan (atas sesuatu benda) kepada badan hukum, orang, negara (pihak lain). Menurut Hukum Perdata, yang dimaksud dengan penyerahan itu adalah, "penyerahan suatu benda oleh pemilik atau atas namanya kepada orang lain sehingga orang lain tersebut memperoleh milik atas benda tersebut."Penyerahan itu dapat dibedakan lagi atas "penyerahan secara nyata dan penyerahan secara yuridis". Penyerahan secara nyata adalah mengalihkan kekuasaan atas suatu kebendaan secara nyata, sedangkan penyerahan secara juridis adalah perbuatan hukum pada mana atau karena mana hak milik (atau hak kebendaan lainnya) dialihkan.

Perbedaan keduanya tampak jelas pada penyerahan benda-benda tak bergerak dan benda-benda bergerak. Pada pendaftaran benda tak bergerak penyerahannya harus melalui pendaftaran pada suatu akta di dalam daftar umum, sebaliknya penyerahan benda-benda bergerak bentuk penyerahan itu dilakukan sekaligus, artinya penyerahan secara nyata dan penyerahan secara juridis dilakukan secara bersama-sama. 


\section{KESIMPULAN}

Berbeda dari pengalihan Paten yang kepemilikan haknya juga beralih, Lisensi melalui suatu perjanjian pada dasarnya hanya bersifat pemberian hak untuk menikmati manfaat ekonomi dari Paten dalam jangka waktu dan syarat tertentu Berbeda dengan produk hki lainnya seperti hak cipta dan merek, paten pada dasarnya hak milik perseorangan yang immateril yang timbul karena kemampuan intelektual manusia. Sebagai hak milik, paten juga dapat dialihkan atau diserahkan oleh Inventornya atau oleh yang berhak atas Invensi itu kepada perseorangan atau badan hukum. Prinsip ideal perlindungan paten sama dengan perlindungan HKI lainnya sepanjang kesemuanya bermaksud untuk melindungi seseorang yang menemukan hal sesuatu agar buah pikiran dan pekerjaannya tidak dipergunakan begitu saja oleh orang lain dan menikmati hasilnya dengan melupakan jerih payah mereka yang telah bekerja keras, berpikir dan mengeluarkan biaya untuk mendapatkannya. Jika dibandingkan antara hak cipta dengan paten, maka perbedaan antara keduanya adalah wujud hak cipta oleh hukum dalam prinsipnya diakui sejak saat semula, dan hukum hanya mengatur dalam

perlindungannya. Sedangkan paten adalah hak yang diberikan oleh negara kepada seseorang yang menemukan sesuatu hal (invensi) dalam bidang teknologi yang dapat diterapkan dalam bidang industri, terhadap satu-satunya orang (eksklusif) yang menemukannya melalui buah pikiran atau buah pekerjaan, dan orang lain dilarang mempergunakannya, kecuali atas izin dari pemilik paten.

\section{DAFTAR PUSTAKA}

\section{Buku}

Dewi Astutty Mochtar, Perjanjian Lisensi Alih Teknologi Dalam Pengembangan Teknologi Indonesia, Bandung: Alumni, 2001.

Soerjono Soekanto, Pengantar Penelitian Hukum, Jakarta: UI-Press, 1986.

Tim Lindsey, Hak Kekayaan Intelektual Suatu Pengantar, Bandung: Alumni, 2006. 